\title{
RELEVANSI PANCASILA ERA INDUSTRY 4.0 DAN SOCIETY 5.0 DI PENDIDIKAN TINGGI VOKASI
}

\author{
Handy Yoga Raharja ${ }^{(1)}$ \\ Unit Mata Kuliah Umum, Politeknik Negeri Batam \\ Jl. Ahmad Yani, Kota Batam, 2946I, Indonesia \\ Email : (I) handy@polibatam.ac.id
}

\begin{abstract}
Pancasila is the basis of the Indonesian state which can be relevant in various scientific fields. Among other things in the field of information and technology which is currently developing rapidly coupled with the revolution of Industry 4.0 and Society 5.0. The revolution is closely related to technological development innovations, as well as the competence of Human Resources. So that Pancasila is very important to take part in improving human resource capabilities, especially in terms of soft skills.
\end{abstract}

Keywords: Pancasila, Industry 4.0, Society 5.0, Soft Skill.

\section{PENDAHULUAN}

Pancasila merupakan dasar negara Republik Indonesia yang dijadikan sebagai acuan dalam berbangsa dan bernegera. Melihat dari historisnya, perumusan Pancasila secara lisan telah disampaikan oleh Muh. Yamin pada tanggal 29 mei 1945 yang berisi peri kebangsaan, peri kemanusiaan, peri ketuhananan, peri kerakyatan, dan kesejahteraan sosial (keadilan sosial). Kemudian Doroeso (1989:123) mengatakan bahwa Pancasila dirumuskan oleh PPKI ( Panitia Persiapan Kemerdekaan Indonesia) yang disahkan menjadi lima sila, yaitu Ketuhanan Yang Maha Esa, kemanusiaan yang adil dan beradab, persatuan Indonesia, kerakyatan yang dipimpin oleh hikmat kebijaksanaan dalam permusyawaratan perwakilan, dan keadilan sosial bagi seluruh rakyat Indonesia.

Pancasila dibentuk agar dapat menjawab semua isu-isu kontemporer yang terus berkembangan hingga saat ini, dilihat dari nilai-nilai yang dituangkan dalam lima sila tersebut. Karena pancasila dijadikan pandangan hidup dan falsafah bangsa Indonesia. Pancasila harus diamalkan pada pembangunan nasional dalam bidang politik, ekonomi, social budaya, pertahanan keamanan, dan teknologi informasi. Sehingga Pancasila tetap memiliki eksistensi disetiap perkembangan jaman, seperti yang saat ini terjadi isu globalisasi merupakan suatu tantangan baru bagi eksistensi nilai-nilai Pancasila. Globasasi membawa berbagai tantangan baru di Indonesia, salah satunya adalah persaingan kemampuan Sumber Daya Manusia (SDM) baik secara hard skill dan soft skill yang menjadi global. Persaingan untuk dunia kerja saat ini tidak hanya antar daerah lokal, melainkan antar negara. Globalisasi juga membawa dampat terhadap perkembangan teknologi, terlihat munculnya revolusi industry 4.0 dan juga Society 5.0.

Pancasila sebagai idologi negara harus ikut andil dalam tantangan baru tersebut. Pancasila sendiri memiliki dimensi fleksibilitas yang mengandung relevansi atau kekuatan yang merangsang SDM untuk mengembangkan 
pemikiran-pemikiran baru terkait nilai-nilai dasar yang terkandung di dalamnya. Sehingga, Pancasila sebagai ideologi bersifat terbuka karena dapat menangkap dinamika internal yang mengundang dan merangsang SDM Indonesia untuk mengembangkan pemikiran baru, tanpa khawatir kehilangan hakikat dirinya. Sehingga Pancasila dianggap penting dalam mempersiapkan SDM di Era industry 4.0 dan Society 5.0.

Perkembangan revolusi tersebut menjadikan pancasila harus mengikuti pola tersebut, terutama di pendidikan tinggi vokasi. Penanaman nilai pancasila pada SDM pendidikan tinggi vokasi sangat penting karena hal tersebut merupakan penguat soft skill SDM. Kedua revolusi tersebut merupakan tantangan tersendiri bagi eksistensi Pancasila.

\section{Perkembangan Revolusi Industry 4.0 dan Society 5.0}

Revolusi Industry 4.0 dan Society 5.0 menurut Andreja (2017:80) merupakan gerakan nyata terhadap perkembangan informasi dan teknologi yang semakin canggih. Kedua revolusi tersebut sebenarnya memiliki esensi yang berbeda, akan tetapi dengan core yang sama yaitu teknologi. Pertama adalah industry 4.0 merupakan industri yang menggabungkan teknologi otomatisasi dengan teknologi cyber. Ini merupakan tren otomatisasi dan pertukaran data dalam teknologi manufaktur. Ini termasuk sistem cyber-fisik, Internet of Things (IoT), komputasi awan dan komputasi kognitif. Menurut Agustini (2018:6) Revolusi indutry 4.0 juga disebut sebagai revolusi industri yang akan mengubah pola dan relasi antara manusia dengan mesin. Inovasi yang diawali dengan besarnya data di internet dan penggunaan cloud mengubah produk industri. Serta mengubah proses produksi dan pemasaran produk. Bahkan mengubah gaya hidup masyarakat karena produk dari revolusi industri ini dapat dilihat penggunaannya di kehidupan sehari-hari. Secara umum revolusi industri keempat ditandai dengan full automation, proses digitalisasi, dan penggunaan alat elektronik dengan sistem informatika. Hal tersebut juga akan mempengaruhi relasi antara customer dengan perusahaan, serta relasi masyarakat umum dengan pemimpin negaranya.

Revolusi industry 4.0 merupakan sesuatu yang tidak dapat ditolak karena telah terlihat bahwa penggunaan berbagai macam hasil produk revolusi industy 4.0 telah dirasakan saat ini. Pada revolusi industri sebelumnya biasanya selalu didominasi oleh negara-negara Eropa dan Amerika yang memiliki berbagai modal yang lebih besar. Akan tetapi, revolusi industy 4.0 memungkinkan setiap negara untuk mengembangkan diri dan meningkatkan kemampuannya secara internal dari segala segi bidang. Karena batas-batas negara akan semakin berkurang dengan masifnya pertukaran informasi di era digital. Indonesia secara umum berada pada posisi tengah dalam revolusi industy 4.0 di ASEAN. Kondisi tersebut bukan berarti Indonesia harus merasa tenang, karena negara lain, seperti Malaysia, Filipina, Vietnam, dan Brunei Darussalam juga berupaya bergerak lebih cepat. Revolusi industry 4.0 memungkinkan tiap negara untuk melakukan leapfrogging. Oleh karena itu Indonesia perlu rencana yang strategis dan segera diimplementasikan Dalam rangka pelaksanaan inovasi era revolusi industri keempat, Indonesia perlu melakukan pemetaan potensi dan tantangannya. Serta merumuskan tujuan dari revolusi industy 4.0 yang akan dikembangkan. Selanjutnya pada perkembangan era ini dibutuhkan kerja sama antara berbagai pihak, baik industri, entrepreneur, pemerintah pusat, pemerintah daerah, serta organisasi kemasyarakatan dalam merumuskan strategi Indonesia menghadapi revolusi industy 4.0.

Kedua adalah Society 5.0 yang sebenarnya juga tidak lepas dari perkembangan teknologi, akan tetapi dalam revolusi ini lebih mengarah pada tatanan kehidupan bermasyarakat, dimana setiap tantangan yang ada dapat diselesaikan melalui perpaduan inovasi dari berbagai unsur yang terdapat pada revolusi industry 4.0. Melalui Society 5.0, kecerdasan buatan yang memperhatikan sisi kemanusiaan akan mentransformasi jutaan data yang 
dikumpulkan melalui internet pada segala bidang kehidupan. Tentu saja diharapkan, akan menjadi suatu kearifan baru dalam tatanan bermasyarakat. Tidak dapat dipungkiri, transformasi ini akan membantu manusia untuk menjalani kehidupan yang lebih bermakna. Dalam Society 5.0, juga ditekankan perlunya keseimbangan pencapaian ekonomi dengan penyelesaian problem sosial.

Society 5.0, nilai baru yang diciptakan melalui inovasi akan menghilangkan kesenjangan regional, usia, jenis kelamin, dan bahasa dan memungkinkan penyediaan produk dan layanan yang dirancang secara halus untuk beragam kebutuhan individu dan kebutuhan laten. Dengan cara ini, akan mungkin untuk mencapai masyarakat yang dapat mempromosikan pembangunan ekonomi dan menemukan solusi untuk masalah sosial. Kedua revolusi tersebut saling berkesinambungan membentuk pola tatanan kehidupan bermasyarakat, yaitu ketika setiap permasalahan dan tantangan yang terdapat didalamnya dapat diselesaikan melalui perpaduan inovasi dari berbagai unsur yang diterapkan pada revolusi industry 4.0 dan kemudian dipadukan dengan society 5.0. Hubungan tersebut diharapkan dapat berperan aktif dalam meningkatkan kualitas kehidupan sosial, sehingga setiap usaha dalam meningkatkan dan mengembangkan revolusi tersebut akan mencermintkan produk dan layanan masyarakat yang bisa diberikan secara berkelanjutan.

Karakteristik di era kedua revolusi tersebut meliputi digitalisasi, optimation dan cutomization produksi, otomasi dan adaptasi, interaksi antara manusia dengan mesin, value added services and business, automatic data exchange and communication, serta penggunaan teknologi informasi. Oleh karen itu, dunia pendidikan tinggi vokasi yang merupakan hilir dari terbentuknya SDM yang berdaya saing global dan industri harus mampu mengembangkan starategi transformasi industri dengan mempertimbangkan sektor SDM yang memiliki kompetensi dibidangnya. Dalam perkembangannya revolusi industy 4.0 harus direspon secara cepat dan tepat oleh seluruh pemangku kepentingan tidak terkecuali dibidanng pendidikan tinggi vokasi agar mampu meningkatkan daya saing bangsa Indonesia ditengah persaingan. Untuk itu Pendidikan Tinggi vokasi wajib merumuskan kebijakan strategis dalam berbagai aspek mulai dari kelembagaan, bidang studi, kurikulum, sumber daya, serta pengembangan cyber university, dan risbang hingga inovasi dengan tanpa tidak melepaskan nilai pancasila sebagai acuan dalam pengembangan kemampuan.

\section{Soft Skill}

Menurut Spencer (1997:5) pendidikan Soft skill merupakan keahlian yang tidak terlihat secara fisik atau lebih dikenal dengan kearah pengembangan kemampuan sikap dan kepribadian yang mendasar untuk mendukung dalam sosialisasi kehidupan manusia. Soft skill dapat dibagi menjadi 3 bagian yaitu tentang kepribadian, konsep diri, sikap mental. Apabila menelaah terkait pengertian soft skill diatas sangat memumngkinkan bahwa kemampuan soft skill yang tinggi tentunya akan menjadikan tingkat kemampuan atau daya saing bangsa ini akan lebih maju, Sebagai contoh negara Jepang bisa melesat maju pasca pengeboman di Hirosima ini disebabkan karena tingkat soft competency (dedikasi, loyalitas, integritas, tingkat kreativitas dan inovasi yang tinggi) dengan mengalihkan kesetian pada dunia militer ke dunia bisnis, sekarang Jepang diakui menjadi negara teknologi. Dalam perkembangan di Indonesia penerepan soft skill akan menjadi pertanyaan besar bagi SDM yang ada, hal ini tidak bisa menyalahkan masa lalu karena berkutat dengan masa lalu kita akan menjadi tambah kerdil, tetapi SDM saat iini harus memikirkan kembali bagaimana membangun kembali karakter Indonesia, hal tersebut dapat dimulai dengan pelaksanaan di dunia pendidikan yang tidak hanya menerapkan hard skill melainkan juga soft skill, sebab dengan motivasi yang tinggi untuk membangun bersama-sama agar bisa jauh lebih baik lagi. 
Soft skill lebih mengacu pada ciri-ciri kepribadian, sosial kebiasan perilaku yang dapat meliputi kemampuan untuk memfasilitasi komunikasi, melengkapi hard skill atau pengetahuan dari berbagai persepsi individu. Elfindri (2010:57) menjelaskan bahwa Ketegori dari soft skill sendiri adalah kualitas pribadi, ketrampilan interpersonal dari pengetahuan. Soft skill merupakan ketrampilan dan kecakapan hidup, baik untuk diri sendiri maupun dengan masyarakat karna seseorang yang mempunyai softskillakan terasa keberadaanya dalam masyarakat. Soft skill meliputi beberapa diantaranya ketrampilan berkomunikasi, ketrampilan berbahasa, memiliki moral dan etika, dan ketrampilan spiritual. Widiastuti (2005:68) Soft skill sangat berpengaruh besar terhadap kesuksesan seseorang, karena dengam mempunyai hardskillsaja tentu tidak lah cukup dalam dunia kerja. Institut Teknologi Camegie menemukan bahwa dari 10.000 orang yang sukses 15\% keberasilan mereka ditentukan oleh ketrampilan, sedangkan $85 \%$ didominasi oleh kepribadian atau soft skill. Penemuan lain menemukan 400 orang atau $10 \%$ dari 4000 orang yang kehilangan pekerjaanya diakibatkan oleh ketidak mampuan teknis, artinya 90\% dari mereka kehilangan pekerjaan diakibatkan oleh masalah kepribadian.

Sharma (2018:38) menyatakan bahwa ada komponen soft skill itu sendiri ada terdapat tujuh elemen atau atribut soft skill yang perlu diimplemasikan dan digunakan dilembaga-lembaga pendidikan. Ketujuh elemen softskilltersebut diantaranya adalah ketrampilan berkomunikasi (communicative skill), ketrampilan berfikir dan memecahkan masalah (thingking skill and problem solving skill), kekuatan kerja tim (teamwork force), manajemen informasi dan kemampuan belajar seumur hidup (life-long learning and information management), Information kemampuan manajemen informasi (management skill), etika, moral dan profesionalisme (ethics, moral \& professional) serta kemampuan kepemimpinan (leadership skill).

Communicative skill (keterampilam komunikasi), keterampilan komunikasi adalah suatu kemampuan seseorang untuk menyampaikan sebuah ide, pesan ataupun gagasan kepada orang lain atau individu secara jelas dan mudah untuk dipahami. Dalam komunikasi yang baik dibutuhkan latihan agar ketrampilan dapat berfungsi serta bermanfaat bagi seseorang untuk mencapai sebuah gagasan untuk menciptakan ketrampilan yang lebih baik dan bermanfaat. Misalnya dalam melakukan suatu tes wawancara, serta hubungan yang baik dalam lingkungan di sekitarnya. Hal ini dapat didefinisikan bahwa komunikasi merupakan pertukaran ide, pikiran, perasaan, serta pemberian nasehat yang terjadi antara individu ataupun kelompok yang dapat bekerjasama. Untuk dapat menyusun dan menghantarkan suatu pesan, ide, ataupun gagasan yang mudah dimengerti dan dipahami dari maksud dan tujuan pemberian pesan.

Critical thinking and problem solving skill (Kemampuan berfikir kritis dan memecahkan masalah) Kemampuan berfikir kritis adalah kemampuan befikir untuk mengidentifikasi dan merumuskan berbagai pokokpokok permasalahan, kemampuan mendeteksi adanya sudut pandang yang berbeda dari suatu ketentua yang diambil dalam mengungkap kemampuan untuk mengevaluasi argument dalam setiap permaslahan dan dapat mengambil keputusan yang tepat. Berfikir kritis merupakan proses berfikir tentang suatu ide atau gagasan dalam suatu permasalahan untuk mengambil keputusan yang akurat sehingga dapat memecahkan suatu permasalahan. Pemecahan masalah pada dasarnya merupakan proses dimana seseorang dapat memyelesaikan suatu pernasalahan yang di hadapi sampai masalah tersebut dapat benar-benar selesai. Sedangkan kemampuan dalam pemecahan masalah yakni kemampuan seseorang atau individu dalam berfikir atau mengambil keputusan dengan proses berfikirnya untum memecahkan suatu permasalahan yang dihadapi.

Teamwork skill (Kemampuan kerjasama tim), Kerjasama tim adalah bentuk kerjasama dalam suatu kelompok yang dapat bekerjasama dengan baik. Tim dapat berangotakan beberapa orang yang memiliki 
keahlian yang berbeda-beda tetapi dapat bekerja sama dengan baik dalam suatu pimpinan. Dalam suatu tim dapat bekerjasama dan ketergantungan satu sama lain untuk mencapai tujuan bersama dan menyelesaikan suatu permasalahan, sehingga diharapkan dapat lebih baik dalam kerjasama tim dibandingkan dengan pemikiran perorangan.

Lift-long learning and information management skill (kemampuan belajar sepanjang hayat dan manajemen informasi), kemampuan tersebut merupakan suatu konsep tentang belajar terus-menerus dan berkesinambungan (continuing-learning) dari lahir sampai akhir hayat, sejalan dengan fase-fase perkembangan pada manusia.Oleh karena setiap fase perkembangan pada masing-masing individu harus dimulai dengan belajar agar dapat memenuhi tugas-tugas perkembanganya, maka belajar itu dimulai dari masa kanak-kanak sampai dewasa dan bahkan masa tua. Tujuan dari proses belajar sepanjang hayat adalah untuk mengembangkan diri, menjadi manusia yang kreatif, sensitif dan dapat berperan aktif dalam proses pembangunan, sehingga bermanfaat bagi orang lain.

Information management skill (kemampuan manajemen informasi), merupakan kemampuan dalam mengidentifikasi informasi yang dibutuhkan, mencari informasi yang relevan dan tepat, dan mengevaluasi informasi tersebut apakah sudah sesuai dengan kebutuhannya, dan menggunakan informasi tersebut untuk menjawab pertanyaan-pertanyaan yang telah diidentifikasi. Jika diorganisasikan dengan baik, maka informasi selanjutnya akan menjadi pengetahuan yang berguna.

Ethic, Moral and Professionalism (etika, moral dan profesionalisme), Ethic (Etika) Kata etika berasal dari kata ethos pada bentuk tunggal berarti kebiasaan, adat istiadat, akhlak, watak, perasaan, sikap dan cara berfikir. Sedangkan dalam bentuk jamak berarti adat kebiasaan, dengan kata lain etika diartikan sebagai ilmu tentang apa yang biasa dilakukan seseorang. Etika dapat berhubungan dengan bagaimana seseorang dapat bertindak dan bagaimana mereka melakukan hubungan dengan orang lain.Ketrampilan etika merupakan kebiasaan bertingkah laku atauberperilaku dalam kehidupan sehari-hari. Jadi seseorang dapat dilihat etikanya dari kebiasaan dirinya bersikap, semakin ia menjunjung tinggi nilai etika, semakin tinggi pula etika yang dia miliki. Etika dan moral hampir memiliki pengertian yang sama, tetapi dalam kehidupan sehari-hari terdapat perbedaan, yaitu moral atau moralitas untuk penilaian perbuatan yang dilakukan, sedangkan etika untuk pengkajian system nilai-nilai yang berlaku. Etika juga dasar terbentuknya moral seseorang. Etika yang berasal dalam diri akal pikiran menjadi dasar untuk menerima suatu kebiasaan yang muncul baik atau buruk.

Moral (Moral), merupakan suatu hubungan atara etika dan moral sangat erat, tetapi keduanya memiliki sifat yang berbeda. Moral lebih mengarah pada suatu ajaran, patokan-patokan, kumpulan peraturan, baik lisan maupun tertulis, tentang bagaimana manusia itu bertindak untuk menentukan langkah menuju yang baik, sedangkan etika lebih pada kebiasaan tingkah laku manusia. Perbuatan manusia bisa dikatakan baik apabila motivasi, tujuan akhir dan lingkungan juga baik. Apabila salah satu perbuatan itu tibak baik, maka manusia itu keseluruhanya kemungkinan tidak baik.

Professionalism (profesionalisme), profesionalisme diartikan sebagai dasar kompetensi klinis, kemampuan berkomunikasi, pemahaman etika dan hokum yang dibangun dengan harapan untuk melaksanakan prinsipprinsip profesionalisme diantarnya: excellenge (keunggulan), humanism (humanisme), accountability (akuntabilitas), altruism (altruism). Profesionalisme pada intinya merupakan suatu kompetensi untuk menjadikan tugas dan fungsi secara baik dan benar. Maka dari profisionalisme itu bukan ditandai dengan 
sekedar penguasaan saja, tetapi juga sangat ditentukan oleh cara memanfaatkan itu serta tujuan yang dicapai sehingga penguasaan dan pemanfaatan dapat dicapai dengan benar dan sesuai.

Leadership skill (ketrampilan kepemimpinan), pengertian kepemimpinan diadopsi dari bahasa inggris yaitu leadership. Leadership berasal dari kata to lead yaitu berupa kata kerja yang berarti memimpin. Lebih lanjut pemaknaan secara terperinci kepemimpinan yaitu orang yang melakukan aktivitas atau kegiatan untuk memimpin atau dapat dimengerti sebagai "a person who leads others a long way guidance". Kepemimpinan merupakan hubungan antara satu dengan yang lain dan saling mempengarui untuk menjadikan tujuan bersama. Kepemimpinan lebih mendasarkan pada iktikat melakukan peran untuk mempengaruhi dan mengarahkan secara efektif. Pemimpin harus mampu mengatasi masalah yang ada, sehingga dapat menciptakan lingkungan yang kondusif. Salah satu faktor terberat dalam pengambilan keputusan adalah pemimpin yang lemah, sehingga tidak dapat memilih keputusan yang baik dan sesuai tujuan. Sedangkan keterampilan dibagi atas tiga macam yaitu keterampilan bersifat teknis yang merupakan ketrampilan untuk mengajarkan dan memberikan aktifitas tekhnis kelmudiann yang kedua adalah ketrampilan hubungan antar manusia yang merupakan ketrampilan yang sanggup untuk bekerjasama dengan anggota kelompok yang dipimpinya. Ketrampilan tersebut akan memotivasi bawahanya sekaligus kemampuan berkomunikasi. Misalnya mampu menggajarkan anggotanya untuk berpendapat ketik ada tutorial, dan yang terkhir adalah keterampilan bersifat konseptual Keterampilan kepemimpinan merupakan keterampilan yang mempengaruhi, memotivasi dan memberi contoh dengan memahami konsep kepemimpinan dan hubungan bawaan untuk mencapai tujuan yang dicapai.

Penjabaran terkait soft skill diatas sangat berhubungan dengan nulai-nilai pancasila, sehingga seharusnya penerapan pancasila dapat dijadikan dasar dalam pengembangan SDM pada ketrampilan soft skill. Nilai-Nilai setiap sila pada pancasila dapat diimplementasikan secara terstruktur ke dalam soft skill, terutama 7 komponen yang telah dijabarkan, hal tersebut merupakan keunggulan tersendiri apabila diterapkan ke dalam pembelajaran karena dapat menjawab kebutuhan perkembangan industri saat ini

\section{Pendidikan Tinggi Vokasi}

Paristiyanti (2016:2) menyatakan bahwa pendidikan tinggi vokasi merupakan motor dalam perkembangan teknologi saat ini dan juga memilik peran yang strategis dan berada di garda terdepan untuk penanganan usia angkatan kerja dan mendidik mereka menjadi tenaga-tenaga terampil, profesional dan memiliki daya kompetitif tinggi yang akan meningkatkan daya saing bangsa. Pendidikan tinggi vokasi harus mampu menghasilkan tenaga kerja terampil dan terlatih yang dibutuhkan oleh dunia industri atau dunia kerja. Pendidikan tinggi vokasi juga ikut serta mendorong agar para lulusannya menjadi wirausahawaan mandiri dan tangguh yang membawanya kedalam kehidupan sejahtera. Pendidikan tinggi vokasi sebagai bagian integral sistem pendidikan nasional menjadi salah satu motor penggerak atau leading sector dalam membangun Indonesia yang sejahtera dan maju.

Pada awalnya pendidikan tinggi vokasi yang dimaksudkan untuk menjembatani (interface) Insinyur dan Operator. Pendidikan tinggi vokasi belum secara spesifik menjawab tantangan bangsa yang berkembang saat ini. Pendidikan tinggi vokasi mengambil peran dalam menghasilkan lulusan kompeten dengan kualifikasi yang cocok dengan tantangan yang dihadapi bangsa Indonesia. Pendidikan tinggi vokasi mampu secara tepat mengidentifikasi kebutuhan di lingkungannya dan menyiapkan proses pembelajaran yang menjamin lulusannya dapat menjawab tantangan tersebut. Selanjutnya, lulusan pendidikan tinggi vokasi harus meredefinisi peran dalam konstelasi pendidikan tinggi di Indonesia yang saat ini mencakup Universitas, Institut, Sekolah Tinggi, Pendidikan tinggi vokasi, Akademi, dan tambahan baru yakni Akademi Komunitas. Lulusan pendidikan tinggi 
vokasi di universitas/akademi maupun politeknik seharusnya didorong bukan hanya dapat "bekerja", karena peran ini sekarang telah diambil alih oleh Akademi Komunitas. Orientasi profil lulusan pendidikan tinggi vokasi perlu dibenahi kembali dan disempurnakan dengan menyertakan postur sebagai "job creator" yang "sadar" dan "faham" akan keunggulan daerahnya.

Menurut Zulhamidi (2016:17) pendidikan vokasi atau yang biasa disebut oleh sebagian besar masyarakat sebagai pendidikan kejuruaan merupakan salah satu jenis program pendidikan tinggi yang diakui oleh negara sebagaimana tercantum pada Bagian Keempat tentang Pendidikan Tinggi dalam Undang-undang No 20 Tahun 2003 tentang Sistem Pendidikan Nasional. Pendidikan Tinggi Vokasi seiiring dengan perkembangan dunia pendidikan pernah mengalami perlakuan sebagai pendidikan yang bukan pilihan utama oleh masyarakat Indonesia, bahkan sampai dengan hari ini terkadang masih beberapa masyarakat masih menganggap seperti itu. Pendidikan vokasi lebih merupakan tempat pelarian apabila calon siswa/mahasiswa tidak diterima di perguruan tinggi program akademik. Perkembangan dunia pendidikan beberapa tahun belakangan menunjukkan perkembangan menggembirakan yang ditandai dengan adanya perhatian serius pemerintah untuk mengembangkan pendidikan vokasi. Pemerintah juga telah fokus pada kerjasama pendidikan khusus vokasi untuk menjawab kebutuhan pasar. Sehingga untuk saat ini kebutuhan SDM pendidikan tinggi vokasi di industri sangat diperhitungkan.

\section{METODE PENELITIAN}

Penelitian ini menggunakan metodologi sesuai dengan apa yang akan dibahas, yaitu meliputi jenis metode penelitian, teknik pengumpulan data, dan juga memiliki batasan masalah yang akan dijelaskan sebagai berikut.

1. Jenis Penelitian

Jenis penelitian yang di gunakan dalam penelitian ini adalah jenis penelitian Deskriptif. Metode penelitian deskriptif merupakan tipe penelitian yang bertujuan untuk menggambarkan secara teperinci tentang fenomena yang terjadi dam menggambarkan gejala atau variable yang dijelaskan secara sistematis, faktual dan aktual menegani fakta-fakta, sifat dan hubungan ntara fenomena yang diamati. Peneliti melakukan pengamatan terhadap hubungan variable yang telah tercantum dalam penelitian. Jadi dalam hal ini peneliti ingin mengamati atau meneliti tentang relevansi Pancasila era industry 4.0 dan society 5.0 di Pendidikan Tinggi .

2. Teknik pengumpulan data

Bedasarkan penelitian ini penulis menggunakan studi pustaka. Dalam teknik penggumpulan data penulis akan mengksplorasi data sesuai dengan pembahasan mengenai relevansi Pancasila era industry 4.0 dan society 5.0 di Pendidikan Tinggi. Dalam hal ini data yang diperoleh dari berbagai buku dan literatur, dokumen, jurnal, artikel maupun informasi dari media cetak meupun media elektronik lainnya yang relevan dalam masalah-masalah yang diamati. Setelah data dikumpulkan, diseleksi dan dikelompokkan akan dilakukan pembahasan dan analisa.

3. Batasan Materi Penelitian

Adapun tujuan untuk menentukan batasan meteri disini agar pembahasan penelitian ini mengenai fenomena yang diamati tidak keluar dari kerangka penelitian yang di tentukan. Upaya pembatasan materi ini agar disamping penulis dapat tetap fokus, penulis dapat terbantu dalam menganalisa data yang sesuai dalam 
pokok bahasan. Sebagai batasan materinya penulis akan menjelaskan tentang bagaimana relevansi Pancasila era industry 4.0 dan society 5.0 di Pendidikan Tinggi melalui metote penelitian yang telah dijabarkan.

\section{HASIL DAN PEMBAHASAN}

Pancasila sebagai dasar Negara yang banyak diwarnai oleh berbagai isu salah satu diantaranya adalah krisis identitas yang terjadi saat ini. Kondisi bangsa Indonesia yang dimasa kolonial selalu menempatkan warga nusantara sebagai pihak yang terkalahkan banyak menginspirasi perumusan Pancasila. Para pendiri bangsa berhasil keluar dari rutinitas pandangan hidup bangsanya, akan tetapi saat ini diharapkan melalui pancasila dapat dijadikan sebagai acuan pengembangan diri dan pedoman dalam peningkatan kemampuan terutama dalam pengembangan soft skill dalam menghadapi penalaran dan kontemplasi yang kontemporer. Pancasila yang juga sebagai dasar negara Indonesia sudah ditentukan oleh para pendiri bernegara, berbagai tantangan dalam menjalankan ideologi pancasila saat ini, karena banyak ideologi luar yang muncul akan tetapi sebenearnya juga tidak akan mampu untuk menggantikankan pancasila sebagai ideologi bangsa Indonesia dengan catatan pancasila terus dipertahankan oleh segenap bangsa Indonesia sebagai dasar negara untuk membuktikan bahwa pancasila merupakan ideologi yang sejati bagi bangsa Indonesia.

Oleh karena itu tantangan di era perkembangan jaman terutama pada revolusi industry 4.0 dan society 5.0 yang bisa mengancam eksistensi Pancasila yang seharusnya kepribadian bangsa, akan tetapi untuk saat ini mengharuskan bangsa Indonesia berada di pusaran arus globalisasi dunia, yang semakin kuat dengan dibarengani perkembangan teknologi yang pesat dengan acuan industry 4.0 dan Society 5.0. Tetapi harus diingat bahwa bangsa dan negara Indonesia jangan sampai kehilangan jati diri, kendati hidup ditengah-tengah pergaulan dunia. SDM yang tumbuh di atas kepribadian bangsa asing mungkin saja mendatangkan kemajuan, akan tetapi kemajuan tersebut juga menjadi suatu ancaman yang akan membuat rakyat tersebut menjadi asing dengan dirinya sendiri dan juga tidak memiliki identitas diri. Hal ini sebenarnya sudah mulai terjadi karena terlihat banyaknya nilai-nilai Pancasila yang mulai diacuhkan. Dalam arus perkembangan teknologi saat ini dimana setiap SDM harus memiliki kemampuan lebih untuk bersaing dengan dunia luar, rakyat dan bangsa Indonesia harus mambuat suatu roadmap terkait implementasi Pancasila di bebagai bidang.

Dalam perkembangan teknologi yang semakin pesat, Indonesia tidak dapat menutup diri dari dunia luar, karena apabila tidak mengikuti perkembangan akan dipastikan tertinggal oleh kemajuan zaman dan kemajuan bangsa-bangsa lain. Bahkan, apabila kita melihat isu yang dulu menjadi pusat perhatian yaitu negara sosialis seperti Uni Soviet yang terkenal anti dunia luar tidak bisa bertahan dan terpaksa membuka diri dan menyesuaikan diri dengan perkembangan yang saat ini berlangsung. Maka konsep pembangunan modern harus membuat Indonesia membuka diri dan mengembangakan diri namun harus dengan landasan Pancasila. Hal tersebut merupakan upaya untuk meletakan dasar-dasar nilai Pancasila agar dapat bersaing sehingga bangsa Indonesia bukan hanya menyerap masuknya modal, teknologi, ilmu pengetahuan, dan ketrampilan dari dunia luar, akan tetapi juga menanamkan nilai-nilai Pancasila di dalamnya. Hal terpenting adalah bagaimana SDM Indonesia mampu menyaring agar hanya nilai-nilai kebudayaan yang baik dan sesuai dengan kepribadian bangsa saja yang terserap. Sebaliknya, nilai-nilai budaya yang tidak sesuai apalagi merusak tata nilai budaya nasional mesti ditolak dengan tegas.

Pancasila harus dapat dijadikan solusi dari persoalan tersebut agar mempertahankan eksistensinya sebagai pandangan hidup dan dasar negara. Apabila bangsa Indonesia konsisten menjaga nilai-nilai luhur bangsa, maka 
nilai-nilai atau budaya dari luar yang tidak baik akan bertolak dengan sendirinya. Akan tetepi permasalahan yang muncul adalah dalam kondisi yang serba terbuka seperti saat ini justru jati diri bangsa Indonesia tengah berada pada titik kritis. Bangsa Indonesia kini seakan-akan tidak mengenal dirinya sendiri sehingga budaya atau nilai-nilai dari luar baik yang sesuai maupun tidak sesuai terserap bulat-bulat. Nilai-nilai yang datang dari luar serta-merta dinilai bagus, sedangkan nilai-nilai luhur bangsa yang telah tertanam sejak lama dinilai menjadi kadaluarsa. Apabila melihat sistem demokrasi yang kini tengah berkembang di Tanah Air yang mengarah kepada ideologi liberalisme yang menjadikan eksistensi Pancasila mulai memudar. Padahal negara Indonesia seperti ditegaskan dalam pembukaan UUD 1945 sangat jelas menganut ideologi demokrasi Pancasila yang berasaskan gotong royong, kekeluargaan, serta musyawarah dan mufakat.

Sifat dari Pancasila itu sendiri sebenarnya dapat menilai mana saja yang bisa diserap untuk disesuaikan dengan nilai-nilai Pancasila sendiri. Dengan begitu, nilai-nilai baru yang berkembang nantinya tetap berada diatas kepribadian bangsa Indonesia. Pasalnya, setiap bangsa di dunia sangat memerlukan pandangan hidup agar mampu berdiri kokoh dan mengetahui dengan jelas arah dan tujuan yang hendak dicapai. Dengan pandangan hidup, suatu bangsamempunyai pedoman dalam memandang setiap persoalan yang dihadapi serta mencari solusi dari persoalan tersebut. Selain itu, Pancasila yang berintikan gotong royong amat sesuai dengan tuntutan Revolusi Industry 4.0 dan Society 5.0 yang mensyaratkan kolaborasi dalam mengembangkan usaha selain responsif terhadap teknologi. Pancasila merupakan dasar yang kuat dalam menjawab tantangan masa depan yaitu dunia usaha berbasis teknologi dan otomatisasi.

Kolaborasi Pancasila perkembangan Revolusi Industry 4.0 dan Society 5.0 akan menjadikan SDM Indonesia semakin kuat, karena perkembangan revolusi tersebut tidak akan lepas dengan keperluan kemampuan soft skill yang juga merupakan nilai-nilai Pancasila. Pancasil merupakan representatif dari kemampuan soft skill yang dibutuhkan di perkembangan revolusi tersebut. Karena dalam kedua revolusi tersebut meskipun mengedepankan teknologi akan tetapi juga membutuhkan SDM yang profesional, sehingga untuk menjawab hal tersebut maka diperlukan dasar hard skill dan soft skill yang kompeten. Jadi salah satu langkah utama yang dapat dilakukan pendidikan pancasila yang ada dalam pendidikan tinggi vokasi harus diperbaiki terutama dalam pengelolaan dan penyampain materi yang harus tersampaikan dengan baik, karena apabila terimplementasi dengan baik maka hal tersebut akan meningkatkan daya saing terhadap kompetitor dan daya tarik bagi mahasiswa.

Relevansi Pancasila terhadap perkembangan Revolusi Industry 4.0 dan Society 5.0 akan terlihat pada penyampaian pengajaran, Pancasila yang merupakan dasar soft skill dapat diterapkan dalam implementasi pengajaran di Pendidikan Tinggi Vokasi, karena dalam Pendidikan Vokasi dituntut mencetak SDM yang berkompeten baik hard skill atau pun soft skill. Perkembangan kedua revolusi tersebut menghadirkan suatu peluang dan ancaman. Dalam satu sisi peluangnya adalah dapat mengimplementasikan Pancasila dalam perkembangan revolusi tersebut, sehingga SDM Indonesia memiliki kompetensi yang profesional dan dapat bersaing dengan era saat ini, karena dengan menanamkan nilai pancasila sebagai soft skill mereka merupakan hal yang sangat baik karena akan menjawab permasalah kebutuhan SDM untuk indutri saat ini. Akan tetapi ada juga ancaman terhadap perkembangan revolusi tersebut, yaitu tidak dapat terimplemntasinya soft skill yang profesional sehingga SDM Indonesia semakain tertinggal dan tidak dapat bersaing dengan dunia luar. 


\section{KESIMPULAN}

Relevansi Pancasila sangat terlihat jelas dalam perkembangan revolusi indusry 4.0 dan Society 5.0, karena tujuan perkembangan tersebut adalah ingin mengintegrasikan tenaga manusia dengan teknologi sehingga ekerjaan yang berhubungan dengan kontak fisik akan berkurang dan diganti dengan sistem otomasi yang semakin canggih, sehingga peluang SDM untuk bekerja akan semakin berat apabila tidak diseimbangi dengan soft skill yang tertuang dalam nilai-nilai Pancasila. Output pendidikan vokasi sendiri adalah membentuk SDM yang berkompeten dalam hal hard skill maupun soft skill. Maka Pancasila era Industry 4.0 dan Society 5.0 di Pendidikan Tinggi Vokasi saat ini harus fleksibel dalam pengimplementasianna akan tetapi tidak lepas dari rule yang ada.

\section{Daftar Pustaka}

Doroeso, B. (1989). Dasar dan Konsep Pendidikan Moral Pancasila. Cetakan 1. Semarang: CV. Aneka Ilmu.

Spencer, Lyle M. (1997). Soft Skill Competencies: Their identification, Measurement and Development. Scottish Council for Research,.

Widiastuti, H. (2005). Pemikiran Visual: alat memetakan pikiran. Terjemahan Visual Thinking : Tools For Mapping Your Ideas (Nancy Margulies dan Christine Valenza).

Elfindri, H. (2010). Soft Skill: untuk Pendidik. Baduose Media.

Nurwardani, P. (2016). Direktorat Jenderal Pembelajaran dan Kemahasiswaan, Panduan Penyusunan Kurikulum

Pendidikan Vokasi, Direktorat Jenderal Pembelajaran dan Kemahasiswaan Kementerian Riset Teknologi dan Pendidikan Tinggi, Cetakan 1.

Zulhamidi \& Edwar, E. (2016). Model Pengembangan Kurikulum Pendidikan Tinggi Vokasi Berbasiskan Standar Kompetensi Kerja Nasional Indonesia/SKKNI (Studi Kasus Program Studi di Politeknik ATI Padang), Jurnal Seminar Nasional Pengembangan Pendidikan Tinggi.

Rojko, A. (2017). Industry 4.0 Concept: Background and Overview. ECPE European Center for Power Electronics e.V. Vol. 11. Nuremberg, Germany.

Sharma, P. (2018). Soft Skills-Personality Development For Life Success. BPB Publications.

Agustini, K.L. (2018). Persaingan Industy 4.0 di ASEAN: Dimana Posisi Indonesia?, Yogyakarta: Forbil Institute.

20 | Handy Yoga Raharja. : Relevansi Pancasila Era Industry 4.0... 